\title{
Sevoflurane Induces DNA Damage Whereas Isoflurane Leads to Higher Antioxidative Status in Anesthetized Rats
}

\author{
Thalita L. A. Rocha, ${ }^{1,2}$ Carlos A. Dias-Junior, ${ }^{1,2}$ \\ Jose S. Possomato-Vieira, ${ }^{1}$ Victor H. Gonçalves-Rizzi, ${ }^{1}$ Flávia R. Nogueira, ${ }^{2}$ \\ Kátina M. de Souza, ${ }^{2}$ Leandro G. Braz, ${ }^{2}$ and Mariana G. Braz ${ }^{2}$ \\ ${ }^{1}$ Department of Pharmacology, Biosciences Institute of Botucatu, Sao Paulo State University (UNESP), Distrito de Rubião Júnior, \\ s/n, 18618-000 Botucatu, SP, Brazil \\ ${ }^{2}$ Department of Anesthesiology, Botucatu Medical School, Sao Paulo State University (UNESP), Distrito de Rubião Júnior, \\ s/n, 18618-970 Botucatu, SP, Brazil
}

Correspondence should be addressed to Carlos A. Dias-Junior; carlosjunior@ibb.unesp.br

Received 29 January 2015; Revised 6 May 2015; Accepted 10 May 2015

Academic Editor: Blanca Laffon

\begin{abstract}
Copyright (c) 2015 Thalita L. A. Rocha et al. This is an open access article distributed under the Creative Commons Attribution License, which permits unrestricted use, distribution, and reproduction in any medium, provided the original work is properly cited.

Taking into account that there are controversial antioxidative effects of inhalational anesthetics isoflurane and sevoflurane and absence of comparison of genotoxicity of both anesthetics in animal model, the aim of this study was to compare DNA damage and antioxidant status in Wistar rats exposed to a single time to isoflurane or sevoflurane. The alkaline single-cell gel electrophoresis assay (comet assay) was performed in order to evaluate DNA damage in whole blood cells of control animals (unexposed; $n=6$ ) and those exposed to $2 \%$ isoflurane $(n=6)$ or $4 \%$ sevoflurane $(n=6)$ for $120 \mathrm{~min}$. Plasma antioxidant status was determined by 3 (4,5-dimethylthiazol-2-yl)-2,5-diphenyltetrazolium bromide (MTT) assay. There was no statistically significant difference between isoflurane and sevoflurane groups regarding hemodynamic and temperature variables $(P>0.05)$. Sevoflurane significantly increased DNA damage compared to unexposed animals $(P=0.02)$. In addition, Wistar rats anesthetized with isoflurane showed higher antioxidative status (MTT) than control group $(P=0.019)$. There were no significant differences in DNA damage or antioxidant status between isoflurane and sevoflurane groups $(P>0.05)$. In conclusion, our findings suggest that, in contrast to sevoflurane exposure, isoflurane increases systemic antioxidative status, protecting cells from DNA damage in rats.
\end{abstract}

\section{Introduction}

The possibility of health hazards resulting from exposure to volatile anesthetics has been extensively discussed during the last decade. There are some epidemiological data suggesting neurotoxic, hepatotoxic, and nephrotoxic side effects from inhalational anesthetics $[1,2]$. Several studies have pointed out genetic damage in operating room personnel exposed to trace concentrations of anesthetic gases [3-5].

Isoflurane $\left(\mathrm{C}_{3} \mathrm{H}_{2} \mathrm{ClF}_{5} \mathrm{O}\right)$ and sevoflurane $\left(\mathrm{C}_{4} \mathrm{H}_{3} \mathrm{~F}_{7} \mathrm{O}\right)$ are inhalational anesthetics widely used in current clinical practice. Both halogenated anesthetics have advantages because of low blood-gas partition coefficients, being sevoflurane with lower solubility (0.65) than isoflurane (1.4), allowing rapid induction and awakening from anesthesia [6].
The genotoxicity and mutagenicity of isoflurane have been evaluated in vitro and in clinical studies showing conflicting results [7-9]. Similar findings are described for sevoflurane [10-12]. Literature is scarce regarding the possible genotoxic effects of isoflurane or sevoflurane in experimental studies. Moreover, no report yet has compared the genotoxicity of isoflurane and sevoflurane in animal model.

So far, the alkaline single-cell gel electrophoresis assay, also known as comet assay, has been extensively used to determine the extent of DNA damage, including strand breaks, alkali-labile sites, DNA cross-linking, and incomplete excision repair sites in mammalian cells [13]. Fragments of DNA migrate farther in response to an electric field, so that the nucleoids resemble a "comet" with a brightly fluorescent head and tail region [14]. This is a rapid, simple, sensitive, and 
reliable biochemical technique for evaluating DNA injury after exposure to toxicants.

It is still controversial whether the volatile anesthetics lead to oxidative stress. Many reports on occupational exposure to anesthetics have shown they can impair antioxidant status [5, $15,16]$. On the other hand, some clinical studies have shown volatile anesthetics do not alter redox status [12, 17].

Because of the absence of reports on genotoxicity together with controversial antioxidative effects of halogenated anesthetics in vivo, the aim of the current study was to compare systemic DNA damage and antioxidant status in rats exposed to either isoflurane or sevoflurane, without undergoing surgery procedure.

\section{Materials and Methods}

2.1. Animals. This study was approved by the Ethical Committee for Animal Research (protocol number 684) from the Biosciences Institute of Botucatu from Sao Paulo State University (UNESP). All animals were treated in accordance with the recommendations of the Ethical Principles approved by the Brazilian Society of Science in Laboratory Animals.

A total of 18 male Wistar rats, weighing 300-350 g, were provided by the Biosciences Institute of Botucatu, UNESP. The animals were maintained at the Department of Pharmacology (UNESP) with restricted-access rooms at a controlled temperature $\left(23 \pm 2^{\circ} \mathrm{C}\right)$ and on a $12 \mathrm{~h}$ light-dark cycle. The animals were given free access to a standard chow diet and drinking water ad libitum, and their age was 10 weeks on the day of exposure.

2.2. Experimental Design. The rats were assigned randomly to one of three groups, each of which consisted of 6 animals that were unexposed (control, C group) or exposed to different volatile anesthetics: isoflurane (Isoforine, Cristalia, Sao Paulo, Brazil; ISO group) or sevoflurane (Sevorane, Abbott, Buenos Aires, Argentina; SEVO group).

Isoflurane and sevoflurane concentrations were recorded by means of an infrared analyzer (Vamos Plus; Dräger, Lübeck, Germany). Induction of anesthesia with 3\% isoflurane or $5 \%$ sevoflurane at a continuous oxygen flow $(2 \mathrm{~L} / \mathrm{min})$ was performed in a glass chamber connected to an anesthesia machine (AI; Insight, Ribeirao Preto, Brazil). Having confirmed immobility and loss of righting reflex, the animals were placed in ventral recumbency on heat pad for preventing hypothermia (Heat Pad; Insight, Ribeirao Preto, Brazil). The anesthetic plan was maintained by face mask with $2 \%$ isoflurane or $4 \%$ sevoflurane.

Subsequently, a polyethylene catheter (PE50) was inserted into the left carotid for evaluation of the mean, systolic, and diastolic arterial pressure. Data were recorded using a data acquisition system (MP150CE; Biopac Systems Inc., Goleta, CA) connected to a computer (Acknowledge 3.2, for Windows). Heart rate values were derived from the blood pressure recordings and processed online. The absence of somatic motor reflexes in response to tail pitching or blinking in response to a low-pressure corneal stimulation indicated deep anesthesia and analgesia. Body temperature was measured using a probe inserted in the rectum of each

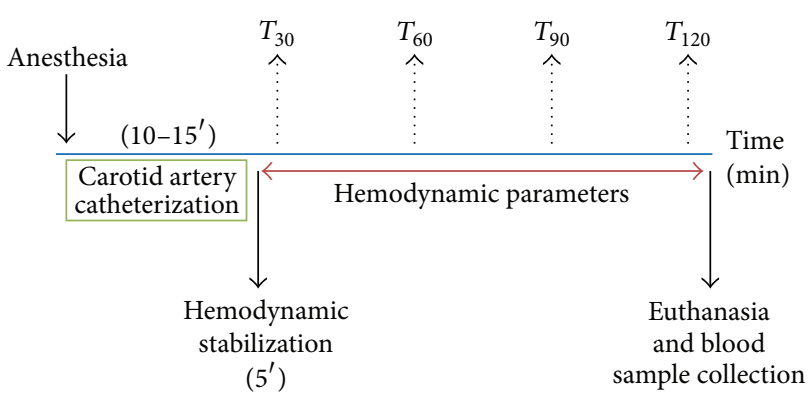

Figure 1: Experimental design for rats exposed to $2 \%$ isoflurane or $4 \%$ sevoflurane for $120 \mathrm{~min}$.

rat, which was connected to a monitor (DX 2023 monitor; Dixtal Biomedica, Sao Paulo, Brazil). The data acquisitions were initiated $30 \mathrm{~min}$ after anesthesia onset [18]. The experimental design for anesthetized rats is presented in Figure 1.

2.3. Blood Collection. Blood was collected in EDTA tubes from each decapitated rat from all groups, and comet assay was carried out immediately. Part of the blood was centrifuged to obtain the plasma, which was aliquoted and stored until evaluation of antioxidant status (MTT assay). All the procedures were performed under dim light to prevent additional DNA damage.

2.4. Genotoxicity Assay. Before performing comet assay, cell viability was determined by trypan blue dye exclusion [19]. The protocol used for the alkaline single-cell gel electrophoresis assay (comet assay) followed the guidelines previously proposed [13]. Briefly, $10 \mu \mathrm{L}$ of fresh peripheral blood cells was added to $100 \mu \mathrm{L}$ of $0.5 \%$ low-melting point agarose at $37^{\circ} \mathrm{C}$, layered onto a precoated slide with $1.5 \%$ regular agarose in duplicate, and covered with a coverslip. After brief agarose solidification in a refrigerator, the coverslip was removed and slides were immersed in lysis solution $(2.5 \mathrm{M} \mathrm{NaCl}$, $100 \mathrm{mM}$ EDTA, and $10 \mathrm{mM}$ Tris, $\mathrm{pH} 10$, with $1 \%$ Triton X-100 and 10\% dimethyl sulfoxide) overnight. Slides were then washed in phosphate-buffered saline (PBS) for $5 \mathrm{~min}$ and immersed in a freshly prepared alkaline buffer $(\mathrm{pH}$ $1 \mathrm{mM}$ EDTA and $300 \mathrm{mM} \mathrm{NaOH}, \mathrm{pH}>13$ ) for $20 \mathrm{~min}$ and the electrophoresis was carried out using the same solution conducted for $20 \mathrm{~min}$ at $25 \mathrm{~V}$ and $300 \mathrm{~mA}$. Following this step, the slides were neutralized in $0.4 \mathrm{M}$ Tris- $\mathrm{HCl}(\mathrm{pH} 7.5)$ for $15 \mathrm{~min}$, fixed in absolute ethanol for $5 \mathrm{~min}$, and stored at room temperature until analysis. The slides were stained with Sybr Gold and a total of 100 randomly captured nucleoids per animal (50 from each slide) were examined blindly by one expert observer at 400x magnification using a fluorescent microscope connected to an image analysis system (Comet Assay IV, Perceptive Instruments, UK) that was calibrated previously according to the manufacturer's instructions. The parameter tail moment was considered to measure DNA damage (arbitrary units).

2.5. Evaluation of Antioxidant Status. Direct reductions in MTT (3-(4,5-dimethylthiazol-2-yl)-2,5-diphenyltetrazolium 
TABLE 1: Hemodynamic variables in anesthetized rats with $2 \%$ isoflurane or $4 \%$ sevoflurane (ISO and SEVO, resp.). Data were recorded at $30\left(T_{30}\right), 60\left(T_{60}\right), 90\left(T_{90}\right)$, and $120 \mathrm{~min}\left(T_{120}\right)$ of anesthesia. Data are presented as mean (S.D.). HR: heart rate; SAP: systolic arterial pressure; MAP: mean arterial pressure; DAP: diastolic arterial pressure. $P>0.05$ among time points in the same group and between groups regarding a specific time point.

\begin{tabular}{lccccc}
\hline \multirow{2}{*}{ Variables } & \multirow{2}{*}{ Groups } & \multicolumn{4}{c}{ Time points } \\
& & $T_{30}$ & $T_{60}$ & $T_{90}$ & $T_{120}$ \\
\hline Heart rate & ISO & $312(30)$ & $326(30)$ & $327(44)$ & $324(46)$ \\
(beats/min) & SEVO & $323(45)$ & $338(32)$ & $357(26)$ & $365(29)$ \\
\hline \multirow{2}{*}{ SAP (mm Hg) } & ISO & $87(13)$ & $90(9)$ & $87(14)$ & $86(16)$ \\
& SEVO & $103(19)$ & $98(15)$ & $98(12)$ & $105(18)$ \\
\hline \multirow{2}{*}{ MAP (mm Hg) } & ISO & $78(9)$ & $84(6)$ & $80(9)$ & $79(12)$ \\
& SEVO & $89(21)$ & $84(17)$ & $84(12)$ & $87(17)$ \\
\hline \multirow{2}{*}{ DAP (mm Hg) } & ISO & $67(10)$ & $73(7)$ & $73(5)$ & $65(11)$ \\
& SEVO & $76(20)$ & $70(15)$ & $71(11)$ & $74(15)$ \\
\hline
\end{tabular}

bromide) were measured as previously described [20] with slight modifications. Briefly, $100 \mu \mathrm{L}$ of plasma was mixed with $12.5 \mu \mathrm{L}$ of dye solution $(5 \mathrm{mg} / \mathrm{mL}$ in $\mathrm{PBS})$; the final volume was adjusted to $200 \mu \mathrm{L}$ with PBS, and the mixture was incubated for $60 \mathrm{~min}$ at $37^{\circ} \mathrm{C}$. The reaction was terminated by the addition of $750 \mu \mathrm{L}$ of $0.04 \mathrm{M}$ hydrochloric acid in isopropanol. The tubes were centrifuged for $10 \mathrm{~min}$ at $1000 \times \mathrm{g}$, the supernatant was collected, and the absorbance was measured at $570 \mathrm{~nm}$.

2.6. Statistical Analysis. Hemodynamic and temperature data were compared between isoflurane and sevoflurane groups and within each group using ANOVA followed by a Tukey test or the $t$-test. For body weight, comet assay, and MTT data, since they showed a normal distribution, ANOVA was applied to compare the three groups, followed by Tukey test, when necessary. A probability value $P<0.05$ was considered statistically significant.

\section{Results}

Table 1 shows no statistically significant difference between isoflurane and sevoflurane groups regarding hemodynamic variables $(P>0.05)$. In addition, body weight did not statistically differ among groups, and rectal temperature data did not differ between isoflurane and sevoflurane groups (data not shown; $P>0.05$ ). None of the animals died during anesthesia.

Cell viability was higher than $98 \%$ for all groups $(99.7 \%$ for control group, $98.2 \%$ for isoflurane group, and $98.9 \%$ for sevoflurane group). The results of the comet assay in the peripheral blood of rats are shown in Figure 2. Sevoflurane significantly increased DNA damage compared to the control $(P=0.02)$. DNA damage was slightly higher in isoflurane group compared to the control, but with no significant difference $(P>0.05)$. No significant differences regarding DNA damage were found between isoflurane and sevoflurane groups $(P>0.05)$.

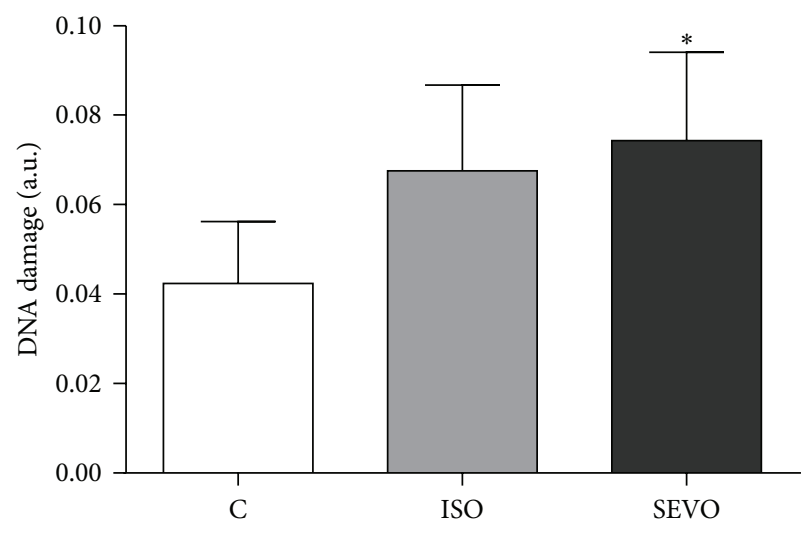

FIGURE 2: DNA damage (mean \pm S.D.) detected by comet assay in whole blood cells of animals unexposed to anesthetics $(\mathrm{C}=$ control) or exposed to $2 \%$ isoflurane (ISO) or $4 \%$ sevoflurane (SEVO). ${ }^{*} \mathrm{P}=$ 0.02 versus control.

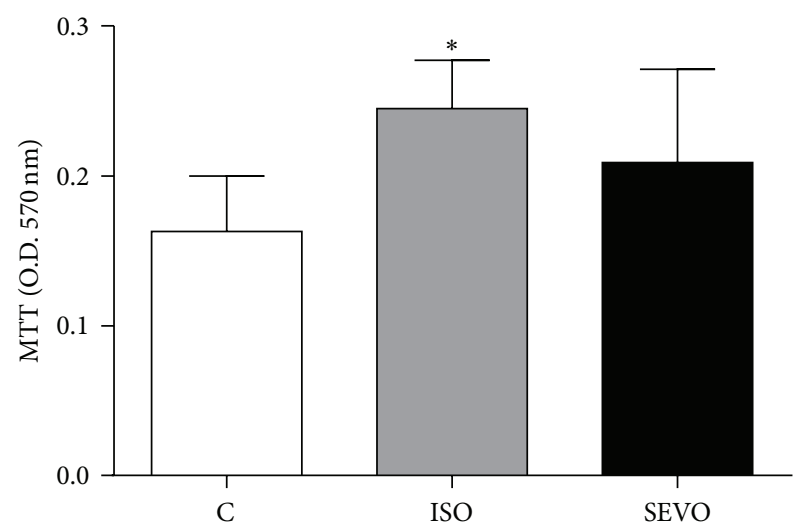

FIGURE 3: Plasma antioxidant status (mean \pm S.D.) of animals unexposed to anesthetics ( $\mathrm{C}=$ control) or exposed to isoflurane (ISO) or sevoflurane (SEVO). ${ }^{*} \mathrm{P}=0.019$ versus control.

Rats anesthetized with isoflurane showed higher antioxidative status (MTT) than control group $(P=0.019)$. There was no significant difference regarding antioxidant capacity between isoflurane and sevoflurane groups $(P>0.05$; Figure 3).

\section{Discussion}

The main findings of the current study are that sevoflurane induced DNA damage whereas isoflurane led to a higher antioxidative status in Wistar rats exposed for $120 \mathrm{~min}$.

The maintenance of hemodynamic stability and rectal temperature were similar in both anesthetics and were relevant since alterations in these parameters may influence the results.

The novelty of this study consists of comparing two different halogenated anesthetics widely used, in rats exposed to a single time for $120 \mathrm{~min}$. Thus, different from clinical practice, we can isolate the role of anesthetic agents from surgery to try to understand the systemic effects of these drugs. Information about genotoxicity of modern halogenated anesthetics is still 
insufficient. Thus, the current study indicates for the first time that rats exposed once to sevoflurane have increased systemic genetic damage within a few hours, when compared to unexposed animals. The concentrations of $2 \%$ and $4 \%$ of isoflurane and sevoflurane, respectively, have already been used in Wistar rats, allowing an adequate anesthesia plan [2123].

Male mice repeatedly exposed to $2.4 \%$ sevoflurane $(2 \mathrm{~h}$ daily, for 3 days) presented more DNA damage in leukocytes detected by comet assay and blood micronucleus compared to the control [24]. Repeated sevoflurane anesthesia (3\% in oxygen for $3 \mathrm{~h} /$ day for 3 consecutive days) was investigated in male rabbits with or without antioxidant supplementation [25]. The authors found that previously vitamin E (50 I.U./day) or selenium ( $15 \mu \mathrm{g} /$ day) supplementation prevented increase of DNA damage in mononuclear cells when compared to nonsupplemented animals exposed to sevoflurane.

Some advantages of sevoflurane in clinical practice include the very low blood and tissue solubility and a pleasant odor. However, about $5 \%$ of inhaled sevoflurane is metabolized in the liver by cytochrome P450 2E1 isoenzyme, giving rise to reactive products, which could directly trigger the generation of peroxynitrite and increase peroxides and nitric oxide [26]. It is known that free radicals or reactive oxygen species (ROS) are major oxidants that react with DNA, damaging it by various lesions, such as oxidized bases, abasic sites, and/or strand breaks [27]. Some authors have also suggested that fluorinated anesthetics, including sevoflurane, could directly lead to DNA damage, and the most probable modification would be an alkylation of purines [8]. Additionally, sevoflurane can induce cellular apoptosis [28]. The observed increase of DNA damage in sevoflurane group may be due to genotoxicity, and not to cell toxicity, since the exposure did not decrease cell viability. Thus, possible mechanisms of sevoflurane genotoxicity include direct genotoxicity and/or oxidative route by metabolism.

Induced DNA damage occurred in blood cells earlier than tissues such as liver, kidney, and brain [24]. According to the authors, blood is the first compartment to absorb sevoflurane and the hematopoietic system may be highly sensitive to genotoxic agents, in part because hematopoietic cells undergo rapid division.

However, a few negative results concerning sevoflurane genotoxicity have already been reported. This anesthetic was not able to induce genetic lesions in vitro, when lymphocytes were exposed to $1 \mathrm{mM}$ or $10 \mathrm{mM}$ at $4^{\circ} \mathrm{C}$ or $37^{\circ} \mathrm{C}$ for 10 and $30 \mathrm{~min}$ [29]. No changes in oxidative DNA damage were observed in adults without comorbidities who underwent minimally invasive surgeries maintained with $1.9 \%$ sevoflurane anesthesia [12].

Different from isoflurane, sevoflurane did not enhance plasma antioxidative status in exposed rats. Similar results were described in literature. A study showed that sevoflurane had no effects on the antioxidant system (glutathione peroxidase and superoxide dismutase enzymes) of anesthetized pigs [30]. Other study revealed that sevoflurane anesthesia did not alter the activities of antioxidant enzymes in the liver, brain, and lung of exposed rats [31]. Additionally, no changes in glutathione peroxidase and catalase activities in rat erythrocytes were detected after $4 \%$ sevoflurane exposure [22].

The International Agency for Research on Cancer (IARC) stated that there is inadequate evidence for the carcinogenicity of isoflurane in animals. Volatile anesthetics are not classifiable as to their carcinogenicity to humans [32]. In the current study, we did not observe a significant difference between comet assay data in isoflurane and sevoflurane groups. Interestingly, any difference was also observed in systemic DNA damage when adult patients were anesthetized with isoflurane or sevoflurane [33]. Supporting our findings, isoflurane was not found mutagenic when evaluated in the bacterial Ames test, using metabolic activation or not, or in Drosophila melanogaster [34, 35].

Contrarily, repeated exposure to isoflurane (1.7\% in oxygen for $2 \mathrm{~h}$ daily for 3 consecutive days) induced genotoxicity in leukocytes and some organs of 8-week-old male Swiss albino mice [21]. Sprague-Dawley rats exposed to isoflurane (1\% in air for $30 \mathrm{~min}$ or $60 \mathrm{~min}$ ) have increased timedependent DNA damage detected in lymphocytes [36]. In contrast, our study showed isoflurane did not increase DNA damage. Differences in isoflurane anesthesia have already been reported in Wistar and Sprague-Dawley rats [37]. Thus, besides animal strain, time (30 or 60 min versus $120 \mathrm{~min}$ ) and concentration of exposure ( $1 \%$ versus $2 \%$ ), animal age (6-8 weeks versus 10 weeks), and target cells analyzed (isolated lymphocytes versus whole blood) are some factors that could explain opposite findings concerning genotoxicity between the studies. Regarding comet assay, we evaluated DNA damage in whole blood cells. Among the advantages of using peripheral blood are the speed, the low cost, and the simplicity in performing the assay and the lower variability of the results [38-40].

It also must be highlighted that, different from sevoflurane, hepatic biotransformation of isoflurane is low $(\leq 0.2 \%)$ [41]. Clinical studies performed by our research group indicated absence of systemic DNA breaks or oxidative DNA damage in patients under isoflurane anesthesia $[9,17]$.

Despite the increase of oxidative stress parameters such as lipid and protein oxidation in rats exposed to isoflurane for $60 \mathrm{~min}$, Kim et al. [36] detected any alteration during the first $30 \mathrm{~min}$. The authors could not show evidence of an association between DNA damage and oxidative stress parameters. Differently, in the current study, we have shown rats anesthetized with isoflurane presented higher plasma antioxidative status. Interestingly, patients undergoing minimally invasive surgery lasting $120 \mathrm{~min}$ showed slight increase of plasma antioxidant capacity during isoflurane anesthesia [17]. Much is still unknown about the possible mechanisms by which isoflurane can have antioxidative properties. It has already been reported that anesthetics can modulate heme oxygenase- (HO-) 1, which exerts anti-inflammatory and antioxidative effects [42]. Isoflurane can induce HO-1 via nuclear factor kappa B (NFkB) [43].

It is already known that anesthetic preconditioning and protection from tissue ischemic injury involve ROS, but the mechanisms are unknown [44]. Thus, isoflurane may provide a benefit against ischemia-reperfusion (IR) injury. 
A study provided evidence that induction of the cytoprotective enzyme HO-1 by nontoxic and clinically approved isoflurane concentration protected rat livers from IR injury [45]. This anesthetic can attenuate oxidative stress and has neuroprotective effects in vitro, but it may work through indirect mechanisms to reduce oxidative stress-induced cell injury [46]. The pretreatment with isoflurane protected cardiomyocytes from damage by oxidative stress; sarcolemmal and mitochondrial Adenosine Triphosphate- (ATP-) sensitive potassium channels play essential and distinct roles in protection afforded by this anesthetic [47]. In addition, isoflurane reduced myocardial infarction size by modulating mitochondrial ROS at clinical concentrations [44]. Certainly further investigations are required to better comprehend the possible mechanisms of antioxidant capacity of isoflurane, especially in a non-IR injury model.

\section{Conclusions}

Under the established conditions, this investigation provides evidence that, in contrast to sevoflurane exposure, isoflurane increases systemic antioxidative status, which can protect cells from DNA damage in rats.

\section{Conflict of Interests}

The authors declare that there is no conflict of interests regarding the publication of this paper.

\section{Acknowledgments}

The authors thank Professor Dr. José Reinaldo C. Braz (Department of Anesthesiology, Botucatu Medical School, UNESP, Botucatu, Brazil) for the critical reading of the paper and the Brazilian funding agencies "Fundacao de Amparo à Pesquisa do Estado de Sao Paulo (FAPESP)" and "Conselho Nacional de Desenvolvimento Cientifico e Tecnologico (CNPq)."

\section{References}

[1] C. J. Green, "Anaesthetic gases and health risks to laboratory personnel: a review," Laboratory Animals, vol. 15, no. 4, pp. 397403, 1981.

[2] R. Lucchini, D. Placidi, F. Toffoletto, and L. Alessio, "Neurotoxicity in operating room personnel working with gaseous and nongaseous anesthesia," International Archives of Occupational and Environmental Health, vol. 68, no. 3, pp. 188-192, 1996.

[3] M. Chandrasekhar, P. V. Rekhadevi, N. Sailaja et al., "Evaluation of genetic damage in operating room personnel exposed to anaesthetic gases," Mutagenesis, vol. 21, no. 4, pp. 249-254, 2006.

[4] T. Wrońska-Nofer, J. Palus, W. Krajewski et al., "DNA damage induced by nitrous oxide: study in medical personnel of operating rooms," Mutation Research-Fundamental and Molecular Mechanisms of Mutagenesis, vol. 666, no. 1-2, pp. 39-43, 2009.

[5] E. R. da Costa Paes, M. G. Braz, J. T. de Lima et al., "DNA damage and antioxidant status in medical residents occupationally exposed to waste anesthetic gases," Acta Cirúrgica Brasileira, vol. 29, no. 4, pp. 280-286, 2014.
[6] E. I. Eger II, "Inhaled anesthetics: uptake and distribution," in Miller's Anesthesia, R. D. Miller, Ed., p. 540, Elsevier, Philadelphia, Pa, USA, 7th edition, 2010.

[7] B. Husum, H. C. Wulf, E. Niebuhr, A. Kyst, and N. Valentin, "Sister chromatid exchanges in lymphocytes of humans anaesthetized with isoflurane," British Journal of Anaesthesia, vol. 56, no. 6, pp. 559-564, 1984.

[8] P. Jałoszyński, M. Kujawski, M. Waşowicz, R. Szulc, and K. Szyfter, "Genotoxicity of inhalation anesthetics halothane and isoflurane in human lymphocytes studied in vitro using the comet assay," Mutation Research, vol. 439, no. 2, pp. 199-206, 1999.

[9] M. G. Braz, M. Á. Mazoti, J. Giacobino et al., "Genotoxicity, cytotoxicity and gene expression in patients undergoing elective surgery under isoflurane anaesthesia," Mutagenesis, vol. 26, no. 3, pp. 415-420, 2011.

[10] L. Karabiyik, S. Şardaş, U. Polat, N. A. Kocabaş, and A. E. Karakaya, "Comparison of genotoxicity of sevoflurane and isoflurane in human lymphocytes studied in vivo using the comet assay," Mutation Research-Genetic Toxicology and Environmental Mutagenesis, vol. 492, no. 1-2, pp. 99-107, 2001.

[11] C. Kaymak, E. Kadioglu, E. Coskun, H. Basar, and M. Basar, "Determination of DNA damage after exposure to inhalation anesthetics in human peripheral lymphocytes and sperm cells in vitro by comet assay," Human and Experimental Toxicology, vol. 31, no. 12, pp. 1207-1213, 2012.

[12] J. E. Orosz, L. G. Braz, A. L. Ferreira et al., "Balanced anesthesia with sevoflurane does not alter redox status in patients undergoing surgical procedures," Mutation Research, vol. 773, pp. 29-33, 2014.

[13] R. R. Tice, E. Agurell, D. Anderson et al., "Single cell gel/comet assay: guidelines for in vitro and in vivo genetic toxicology testing," Environmental and Molecular Mutagenesis, vol. 35, no. 3, pp. 206-221, 2000.

[14] P. L. Olive, J. P. Banáth, and R. E. Durand, "Heterogeneity in radiation-induced DNA damage and repair in tumor and normal cells measured using the 'comet' assay," Radiation Research, vol. 122, no. 1, pp. 86-94, 1990.

[15] Z. Baysal, M. Cengiz, A. Ozgonul, M. Cakir, H. Celik, and A. Kocyigit, "Oxidative status and DNA damage in operating room personnel," Clinical Biochemistry, vol. 42, no. 3, pp. 189-193, 2009.

[16] S. Izdes, S. Sardas, E. Kadioglu, and A. E. Karakaya, "DNA damage, glutathione, and total antioxidant capacity in anesthesia nurses," Archives of Environmental and Occupational Health, vol. 65, no. 4, pp. 211-217, 2010.

[17] M. G. Braz, L. G. Braz, J. R. Braz et al., "Comparison of oxidative stress in ASA physical status I patients scheduled for minimally invasive surgery under balanced or intravenous anesthesia," Minerva Anestesiologica, vol. 79, no. 9, pp. 1030-1038, 2013.

[18] M. F. Montenegro, E. M. Neto-Neves, C. A. Dias-Junior et al., "Quercetin restores plasma nitrite and nitroso species levels in renovascular hypertension," Naunyn-Schmiedeberg's Archives of Pharmacology, vol. 382, no. 4, pp. 293-301, 2010.

[19] V. J. McKelvey-Martin, M. H. L. Green, P. Schmezer, B. L. Pool-Zobel, M. P. De Méo, and A. Collins, "The single cell gel electrophoresis assay (comet assay): a European review," Mutation Research, vol. 288, no. 1, pp. 47-63, 1993.

[20] L. O. Medina, C. A. Veloso, É. de Abreu Borges et al., "Determination of the antioxidant status of plasma from type 2 diabetic patients," Diabetes Research and Clinical Practice, vol. 77, no. 2, pp. 193-197, 2007. 
[21] G. Brozovic, N. Orsolic, F. Knezevic et al., "The in vivo genotoxicity of cisplatin, isoflurane and halothane evaluated by alkaline comet assay in Swiss albino mice," Journal of Applied Genetics, vol. 52, no. 3, pp. 355-361, 2011.

[22] F. J. L. Bezerra, N. B. do Vale, B. D. O. Macedo, A. A. Rezende, and M. D. G. Almeida, "Evaluation of antioxidant parameters in rats treated with sevoflurane," Revista Brasileira de Anestesiologia, vol. 60, no. 2, pp. 93-169, 2010.

[23] F. S. Guedes Jr., D. S. Cruz, M. M. Rodrigues et al., "Renal histology and immunohistochemistry after acute hemorrhage in rats under sevoflurane and ketoprofen effect," Acta Cirúrgica Brasileira, vol. 27, no. 1, pp. 37-42, 2012.

[24] G. Brozovic, N. Orsolic, R. Rozgaj et al., "DNA damage and repair after exposure to sevoflurane in vivo, evaluated in Swiss albino mice by the alkaline comet assay and micronucleus test," Journal of Applied Genetics, vol. 51, no. 1, pp. 79-86, 2010.

[25] C. Kaymak, E. Kadioglu, H. Basar, and S. Sardas, "Genoprotective role of vitamin $\mathrm{E}$ and selenium in rabbits anaesthetized with sevoflurane," Human \& Experimental Toxicology, vol. 23, no. 8, pp. 413-419, 2004.

[26] G. Brozovic, N. Orsolic, F. Knezevic et al., "Evaluation of DNA damage in vivo induced by combined application of cisplatin and sevoflurane," European Journal of Anaesthesiology, vol. 25, no. 8, pp. 642-647, 2008.

[27] J. Cadet, T. Douki, D. Gasparutto, and J. L. Ravanat, "Oxidative damage to DNA: formation, measurement and biochemical features," Mutation Research-Fundamental and Molecular Mechanisms of Mutagenesis, vol. 531, no. 1-2, pp. 5-23, 2003.

[28] H. Matsuoka, S. Kurosawa, T. Horinouchi, M. Kato, and Y. Hashimoto, "Inhalation anesthetics induce apoptosis in normal peripheral lymphocytes in vitro," Anesthesiology, vol. 95, no. 6, pp. 1467-1472, 2001.

[29] K. Szyfter, R. Szulc, A. Mikstacki, I. Stachecki, M. Rydzanicz, and P. Jałoszyński, "Genotoxicity of inhalation anaesthetics: DNA lesions generated by sevoflurane in vitro and in vivo," Journal of Applied Genetics, vol. 45, no. 3, pp. 369-374, 2004.

[30] B. Allaouchiche, R. Debon, J. Goudable, D. Chassard, and F. Duflo, "Oxidative stress status during exposure to propofol, sevoflurane and desflurane," Anesthesia and Analgesia, vol. 93, no. 4, pp. 981-985, 2001.

[31] H. Türkan, A. Aydin, A. Sayal, A. Eken, C. Akay, and B. Karahalil, "Oxidative and antioxidative effects of desflurane and sevoflurane on rat tissue in vivo," Arhiv za Higijenu Rada $i$ Toksikologiju, vol. 62, no. 2, pp. 113-119, 2011.

[32] MRC Monograph on the Evaluation of Carcinogenic Risks to Humans: Overall Evaluation of Carcinogenicity: An Update of IARC Monographs Volumes 1 to 42, supplement 7, International Agency for Research on Cancer (IARC), Lyon, France, 1987.

[33] M. G. Braz, L. G. Braz, B. S. Barbosa et al., "DNA damage in patients who underwent minimally invasive surgery under inhalation or intravenous anesthesia," Mutation Research: Genetic Toxicology and Environmental Mutagenesis, vol. 726, no. 2, pp. 251-254, 2011.

[34] J. M. Baden, M. Kelley, R. S. Wharton, B. A. Hitt, V. F. Simmon, and R. I. Mazze, "Mutagenicity of halogenated ether anesthetics," Anesthesiology, vol. 46, no. 5, pp. 346-350, 1977.

[35] Y. R. Kundomal and J. M. Baden, "Mutagenicity of inhaled anesthetics in Drosophila melanogaster," Anesthesiology, vol. 62, no. 3, pp. 305-309, 1985.

[36] H. Kim, E. Oh, H. Im et al., "Oxidative damages in the DNA, lipids, and proteins of rats exposed to isofluranes and alcohols," Toxicology, vol. 220, no. 2-3, pp. 169-178, 2006.
[37] J. M. Siller-Matula and B. Jilma, "Strain differences in toxic effects of long-lasting isoflurane anaesthesia between Wistar rats and Sprague Dawley rats," Food and Chemical Toxicology, vol. 46, no. 11, pp. 3550-3552, 2008.

[38] G. Speit, T. Witton-Davies, W. Heepchantree, K. Trenz, and H. Hoffmann, "Investigations on the effect of cigarette smoking in the comet assay," Mutation Research-Genetic Toxicology and Environmental Mutagenesis, vol. 542, no. 1-2, pp. 33-42, 2003.

[39] C.-H. Chuang and M.-L. Hu, "Use of whole blood directly for single-cell gel electrophoresis (comet) assay in vivo and white blood cells for in vitro assay," Mutation Research/Genetic Toxicology and Environmental Mutagenesis, vol. 564, no. 1, pp. 75-82, 2004.

[40] M. G. Braz and D. M. F. Salvadori, "Influence of endogenous and synthetic female sex hormones on human blood cells in vitro studied with comet assay," Toxicology in Vitro, vol. 21, no. 5, pp. 972-976, 2007.

[41] J. L. Martin Jr. and D. B. Njoku, "Metabolism and toxicity of inhaled anaesthetics," in Miller's Anesthesia, R. D. Miller, Ed., p. 262, Elsevier, Philadelphia, Pa, USA, 6th edition, 2005.

[42] A. Hoetzel and R. Schmidt, "Regulatory role of anesthetics on heme oxygenase-1," Current Drug Targets, vol. 11, no. 12, pp. 1495-1503, 2010.

[43] G. Li Volti, F. Basile, P. Murabito et al., "Antioxidant properties of anesthetics: the biochemist, the surgeon and the anesthetist," La Clinica Terapeutica, vol. 159, no. 6, pp. 463-469, 2008.

[44] N. Hirata, Y. H. Shim, D. Pravdic et al., "Isoflurane differentially modulates mitochondrial reactive oxygen species production via forward versus reverse electron transport flow: implications for preconditioning," Anesthesiology, vol. 115, no. 3, pp. 531-540, 2011.

[45] R. Schmidt, E. Tritschler, A. Hoetzel et al., "Heme oxygenase1 induction by the clinically used anesthetic isoflurane protects rat livers from ischemia/reperfusion injury," Annals of Surgery, vol. 245, no. 6, pp. 931-942, 2007.

[46] S.-A. Lee, J.-G. Choi, and Z. Zuo, "Volatile anesthetics attenuate oxidative stress-reduced activity of glutamate transporter type 3," Anesthesia and Analgesia, vol. 109, no. 5, pp. 1506-1510, 2009.

[47] J. Marinovic, Z. J. Bosnjak, and A. Stadnicka, "Distinct roles for sarcolemmal and mitochondrial adenosine triphosphatesensitive potassium channels in isoflurane-induced protection against oxidative stress," Anesthesiology, vol. 105, no. 1, pp. 98104, 2006. 


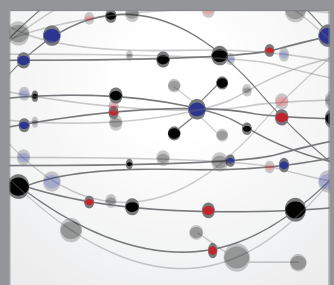

The Scientific World Journal
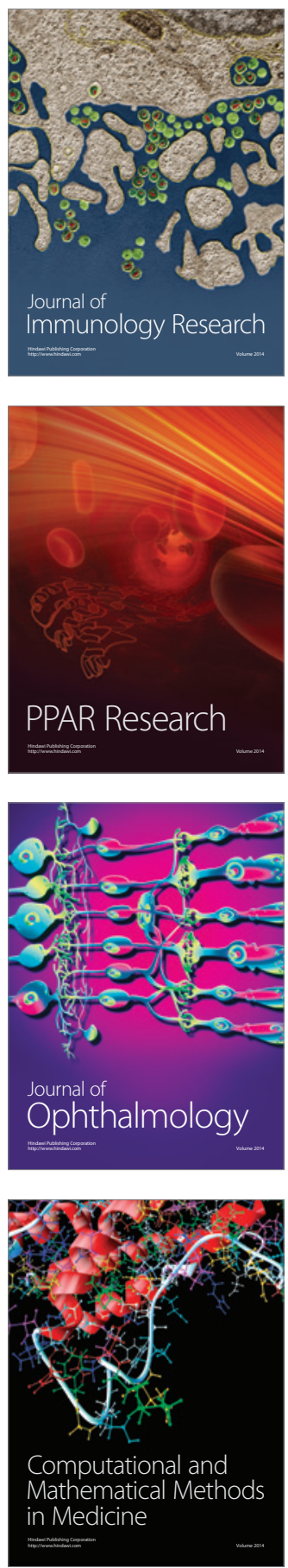

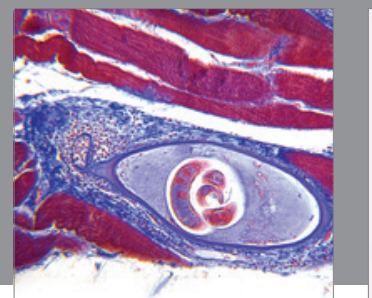

Gastroenterology

Research and Practice
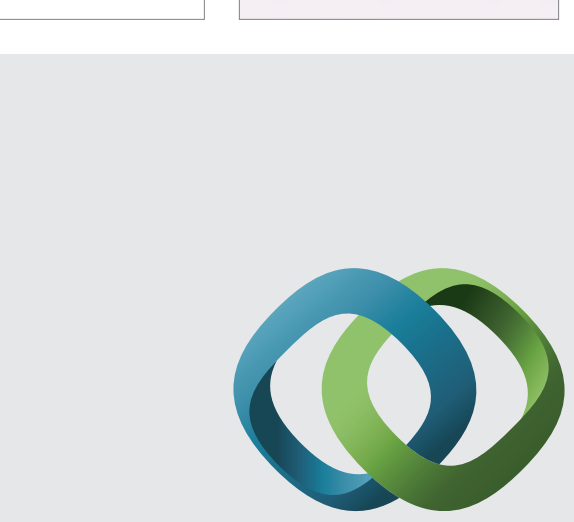

\section{Hindawi}

Submit your manuscripts at

http://www.hindawi.com
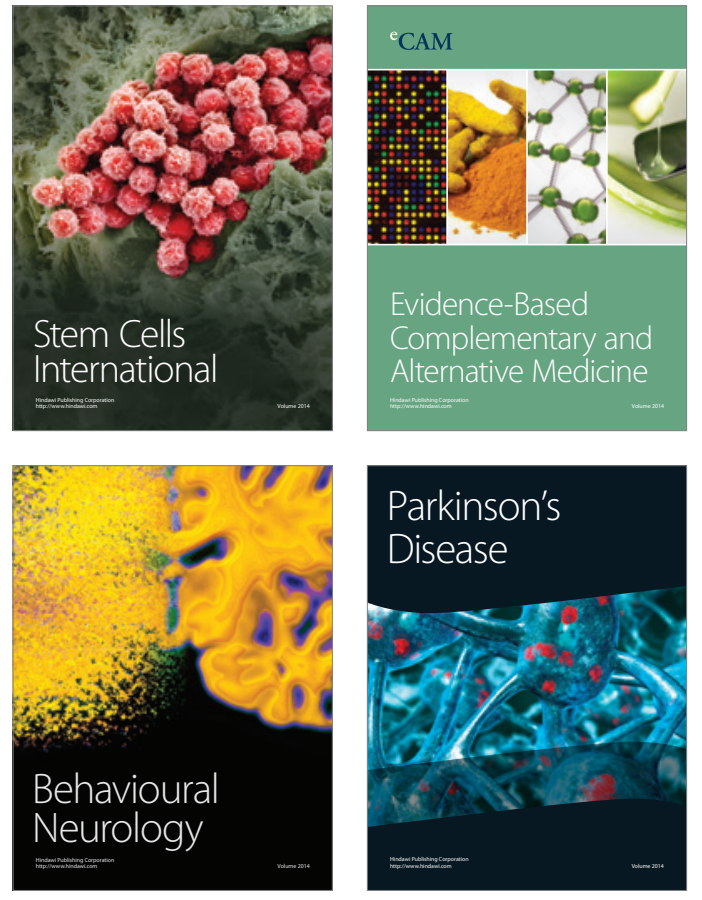
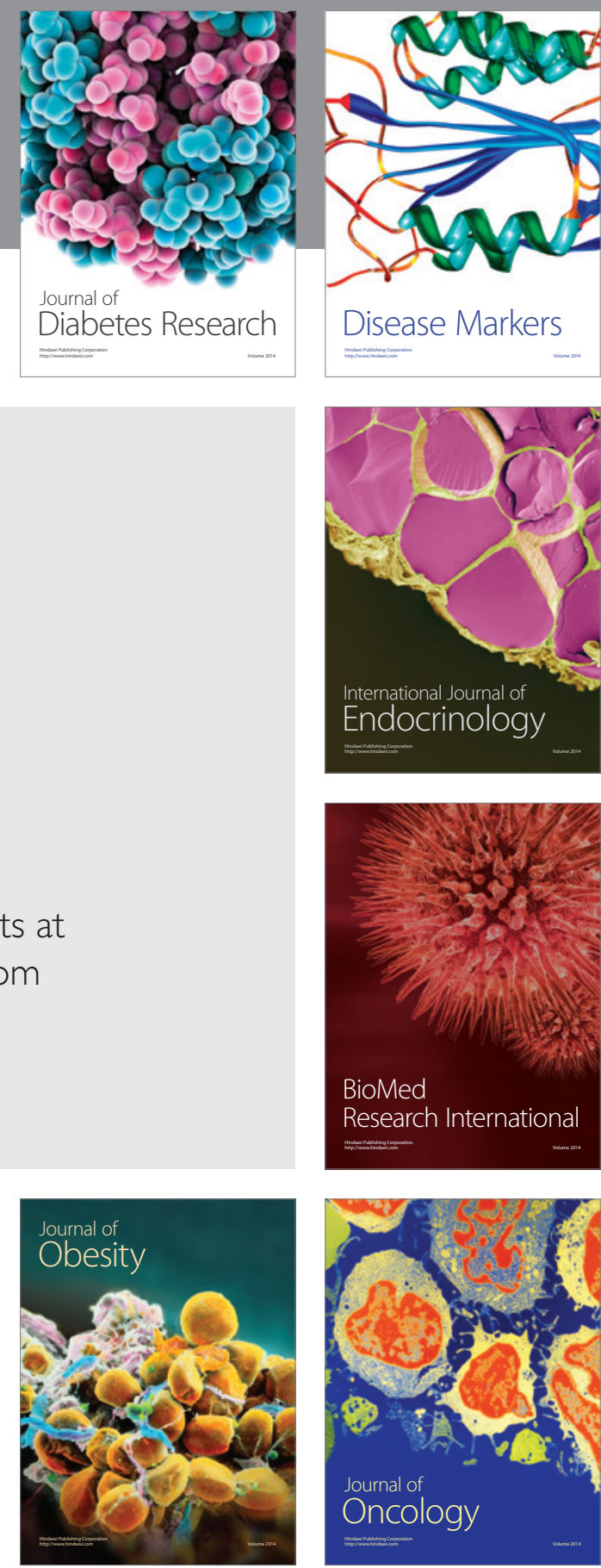

Disease Markers
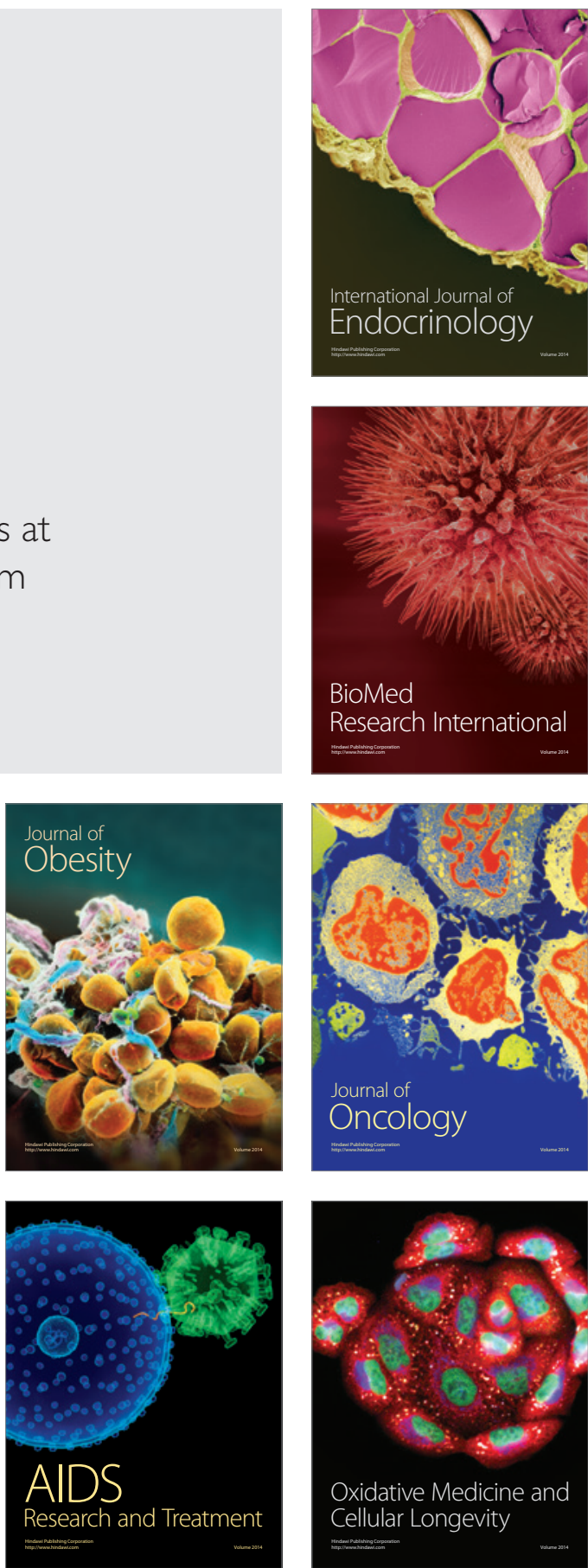